\title{
Specifics of the Body Image of Adolescents with Scoliosis: A Case of Being Labeled as 'A Scoliotic'
}

\author{
Vladyslav Deputatov* and Mariana Velykodna
}

\author{
Practical Psychology Department, Kryvyi Rih State Pedagogical University, Kryvyi Rih, Prospekt Haharina 54, \\ office 303, 50086, Ukraine
}

\begin{abstract}
The body image is to be reconstructed during adolescence, which is more difficult in the case of somatic illness and social stigma. This research aimed to study adolescents' body image with scoliosis, students of a special educational institution in Ukraine socially identified with stigma as 'a school for scoliotics'.

The participants $(n=104)$ of the research were adolescents (13-15 years old) with scoliosis from the institution mentioned above ( $n=52,24$ males, 28 females) and adolescents without scoliosis from the same city ( $n=52,24$ males, 28 females). Two methods were used to collect the data: (1) Self-portraits; (2) Dembo-Rubinstein Self-Assessment Scale.

The adolescents with scoliosis and labeled as 'scoliotics' face additional obstructions in their psychic body development compared to their peers. For instance, they tend to overinvest in the desired image of a healthy body and do not feel able to get it. We found the markers of four different ways to cope with the situation by the adolescents with scoliosis: (a) identification as 'a scoliotic' instead of hope to be cured soon; (b) psychological distancing from the others to preserve the desire of a more attractive body image; (c) repression or denial of the body parts which could relate to scoliosis; (d) infantilization, aimed to slow down the discovery of their maturing corporeality. Consequently, adolescents with scoliosis affected by stigma experience the gap or conflict between their current, desired and perceived realistic body image.
\end{abstract}

Keywords: Adolescence, body image, scoliosis, self-portrait, social stigma.

\section{INTRODUCTION}

The period of adolescence is the time of several body-related discoveries. Due to puberty and its substantial body changes, adolescents discover their new looks and new feelings [1, 2], genital sexuality [3], "feminine" as not just "non-masculine" [4], and experience mourning for their previous childish body and the child's place [5]. Therefore, their previously developed body image (more as a dynamic relation than a static product [6]) is to be fundamentally reconsidered and reconstructed during this period [719].

Here and below, we use the term 'body image' as a psychic representation [20,21], partly conscious, which reflects, unites, and interprets 'the body parts and their relative position, and involves both the subject's perceptual body experience with the body limits and conceptual understanding of the body in general' [22, 23]. Body image is always 'highly influenced by cognitive, affective, attitudinal, and other variables' [24], which has its positive consequences [25, 26], for instance, to become a bodily base for the development and functioning of the ego.

It is evident that body image has some specifics in the case of somatic illness, e.g., rheumatoid arthritis,

*Address correspondence to this author at the Kryvyi Rih, Almazna street 12, Apt. 2, 50025, Ukraine; Tel: +380988977284; E-mail: 30.mm.bb@gmail.com cancer [27, 28], chronic illnesses [29], unilateral cerebral palsy [22], physical disabilities [30], psoriasis [31], scoliosis [32]. Similarly, it has its specifics in case of psychic, personal or behavior disorders, e.g., schizophrenia [33], eating disorders [34-38], and depression [39]. Besides, researchers emphasize the sociocultural influence on body image development, e.g., by the media, internet, ethnicity, etc. [40-51].

Therefore, it may pose a great challenge to reconstruct one's own body image while being an adolescent with a certain medical condition, especially related to the body, like scoliosis. Another particular situation is the case when an adolescent has to be identified by his or her illness and faces the stigma. For instance, in Kryvyi Rih, Ukraine, there is an educational institution widely known in the city as a 'school for scoliotics' (here we quote current social stigma). It was founded in the USSR in 1960 and aimed at combining a secondary school with the goals to treat scoliosis by certain everyday physical training.. Actually, this institution was renamed from 'Sanatorium boarding school No. 7 for children with scoliosis' to 'Secondary sanatorium boarding school No. 7' in 1994, and to 'Kryvyi Rih lyceum "Grand"' only in November 2020 (i.e., after this research has been conducted); however, the social attitude and the goals of the institution had been focused on scoliosis of pupils until these days. Although this stigma does not have negative connotations and the mentioned school is respected in the city, the pupils who were going to this educational 
institution knew they were doing this because of their scoliosis and everyone else also still identifies them as 'scoliotics' in 'a school for scoliotics'. How does this (i.e., their scoliosis and their position at school as 'scoliotics') touch their body image development in adolescence? This is the main question of this paper.

Thus, the objective of this paper is to present the results of an empirical study on the body image of adolescents with scoliosis who study in a special educational institution socially identified with a stigma as 'a school for scoliotics'.

\section{MATERIALS AND METHODS}

\subsection{Setting and Participants}

The study was designed to obtain quantitative data on the body images of adolescents, which enabled further statistical analysis.

The study was reviewed and approved by the Local Ethics Committee of the Practical Psychology Department of Kryvyi Rih State Pedagogical University (Kryvyi Rih, Ukraine).

The experimental group participants were Ukrainian schoolers studying at a special municipal secondary educational institution for adolescents with scoliosis. The participants from the control group were Ukrainian adolescents without scoliosis from another municipal middle school in the same city.

\subsection{Procedure}

The study was conducted from October 2018 to May 2019. Parents' written consent for the adolescents' participation in the research, for gathering the personal data, and for publishing the results had been gathered a month before the study was commenced. Moreover, the participation was voluntary for the adolescents themselves.

\subsection{Material Development}

To the date of the choice of the research design, several attempts to elaborate the ways for measuring body image had been made by different authors [22, 52-63]. According to the objective of the study, in our research, we assessed quantitative data on body images using the Self-portraits of adolescents, which is an altered version of the 'Draw-a-Man' test [64], as the main method, and a modified version of DemboRubinstein self-assessment scale [65], adapted for our goals, as an additional source.

\subsubsection{Self-Portraits}

Adolescents were asked to draw themselves (the word 'body' or 'body image' were not mentioned in the instruction) on a standard piece of paper, A4 size, with gray or colored pencils. Self-portraits were drawn in a single form; respondents were offered to use eight pencils of different colors (blue, green, red, yellow, violet, brown, black, gray); a time limit of 20 minutes was set.

To calculate the quantitative data from self-portraits, we converted the present or absent elements of the picture into dichotomous scales, convenient for statistical analysis. They were constructed based on the interpretable items suggested by Burns et al. [66] and Romanova et al. [67]. In total, we have allocated 11 dichotomous scales (yes/no): 1) presence of the whole body, 2) oversimplification of the drawn person, 3) ability to identify the sex of the drawn person, 4) visible curvature of the drawn person's back (asymmetry of the left and right sides), i.e., looking like scoliosis, 5) strong hatching, 6) graphic 'lapsus' in the form of unnecessary lines, 7) graphic 'lapsus' in the form of traces of erased pencil marks, 8) use of colored pencils, 9) limbs of the drawn person are not visible, 10) landscape paper orientation, 11) the presence of background (see Appendix A). Besides, the time spent on drawing and the height of the drawn person were also measured.

\subsubsection{Dembo-Rubinstein Self-Assessment Scale}

Adolescents were offered a blank with $10-\mathrm{cm}$ vertical lines and instructions (Appendix B). They were orally instructed on the example of the first line that this is such a continuum, where there is the healthiest human in the world on the top. At the same time, on the bottom, there is the sickest human in the world, while between them, there is all the humanity, including the respondent. Then he or she needs to place three different marks on the lines, answering three questions ("Where are you now between them?", "Where do you want to be?", "Where may you get in the future?"). After that, the instructions are repeated for the second line using another category. Prikhozhan's version of this scale has seven categories: health, intelligence, temper, authority, skills, appearance, and selfconfidence [65]. To meet our research goals, we added one more: the body. After quantitative analysis, which involved measuring the location of a point from a nominal zero (the lowest point) in millimeters, we obtained the numeral data from about 24 answers; however, we were most interested in the nine of them: 
"health I currently have", "health I want to have", "health I can get in the future", "body I currently have", "body I want to have", "body I can get in the future", "appearance I currently have", "appearance I want to have", "appearance I can get in the future" (see Appendix C).

\subsection{Statistical Analysis}

Data analysis of this study included descriptive statistics, non-parametric comparison by MannWhitney criterion, Pearson $\mathrm{X}^{2}$-test, Spearman rankorder correlation, and Fisher's $\varphi^{*}$-test using IBM SPSS Statistics 23 software.

\section{RESULTS}

\subsection{Participants}

In the experimental group, 68 adolescents were invited to participate in the research. Among them, four declined the invitation, 12 have not completed the whole list of diagnostic methods due to different reasons; thus, the data were obtained from 52 adolescents aged 13 to $15(M=14.1, S D=0.88)$. There were male $(n=24)$ and female $(n=28)$ respondents among them. All the participants had scoliosis as their medical diagnosis, which was the reason for studying in those mentioned above special educational institutions.

In the control group, we gathered the responses from 52 adolescents ( 24 males and 28 females) without scoliosis aged 13 to $15(\mathrm{M}=13.8, \mathrm{SD}=0.67)$.

\subsection{Body Image of Adolescents with Scoliosis}

First of all, the collected self-portraits were analyzed and summarized by those mentioned above 11 dichotomous scales, which described different aspects of body representations (Table 1). As shown in Table 1, male and female adolescents from the experimental group did not differ significantly by the studied scales according to Fisher's $\varphi^{*}$-test.

Besides, we compared these adolescents by each scale (i.e., those who have present or absent elements of the picture) via Pearson $x^{2}$-test to count frequencies of the presence or absence of the certain element in the studied group. Therefore, in general, both male and female adolescents with scoliosis tended to draw portraits with recognizable sex $\left(x^{2}=61.54, p<0.01\right)$, without background $\left(x^{2}=61.54, p<0.01\right)$, and avoiding oversimplified drawings $\left(x^{2}=55.54, p<0.01\right)$ as well as unnecessary lines $\left(x^{2}=30.15, p<0.01\right)$.

The height of the drawn person (in $\mathrm{mm}$ ) strongly and significantly correlated with the time (in min) spent on drawing $(r=0.644, p<0.01)$ in a direct way, and there was a weak reverse correlation with the presence of the whole body $(r=-0.295,0.01<p<0.05)$. Searching for connections with the data collected by the DemboRubinstein self-assessment scale, we found a moderate significant reverse correlation between the presence of any background and the scale "body that I want to have" $(r=-0.342,0.01<p<0.05)$.

\subsection{Body Image of Adolescents from a Control Group (without Scoliosis)}

As for the adolescents from the control group, we found significant differences between the male and female self-portraits by three scales (see Table 2). The statistical analysis showed that male adolescents were more likely to draw themselves more simplistically $\left(\varphi^{*}=2.484, \quad p<0.01\right)$. At the same time, female adolescents from the control group spent more time on drawing $(U=159.5, p<0.01)$ and more often preferred to add a background $\left(\varphi^{*}=2.279, \mathrm{P}<0.05\right)$.

In general, both male and female adolescents without scoliosis tended to draw a portrait with recognizable sex $\left(x^{2}=74.46, p<0.01\right)$, with the presence of the whole body $\left(x^{2}=30.15, p<0.01\right)$ and portrait orientation of the paper $\left(x^{2}=49.85, p<0.01\right)$, to avoid oversimplification of the drawing $\left(x^{2}=39.38, p<0.01\right)$ and drawing unnecessary lines $\left(x^{2}=39.38, p<0.01\right)$, not to use colored pencils $\left(x^{2}=55.54, p<0.01\right)$ and not to draw any background $\left(x^{2}=49.85, p<0.01\right)$, as well as to draw all the limbs of the depicted person $\left(x^{2}=61.54\right.$, $p<0.01$ ).

The height of the drawn person was moderately correlated with the time spent on drawing $(r=0.389$, $p<0.01)$ in a direct way. Searching for relations with the data collected by Dembo-Rubinstein self-assessment scale, we found a moderate reverse correlation between the time spent on drawing and the scales "health I currently have" $(-0.497, p<0.01)$ as well as "health I can get in future" $(-0.306, p<0.05)$, besides, there was a moderate reverse correlation with the scale "appearance I currently have" $(-0.345, p<0.05)$. At the same time, there was a moderately significant correlation between the scale "health I currently have" and the graphic 'lapsus' in the form of traces of erased pencil marks $(-0.358, p<0.01)$. 
Table 1: The Body Image (Experimental Group)

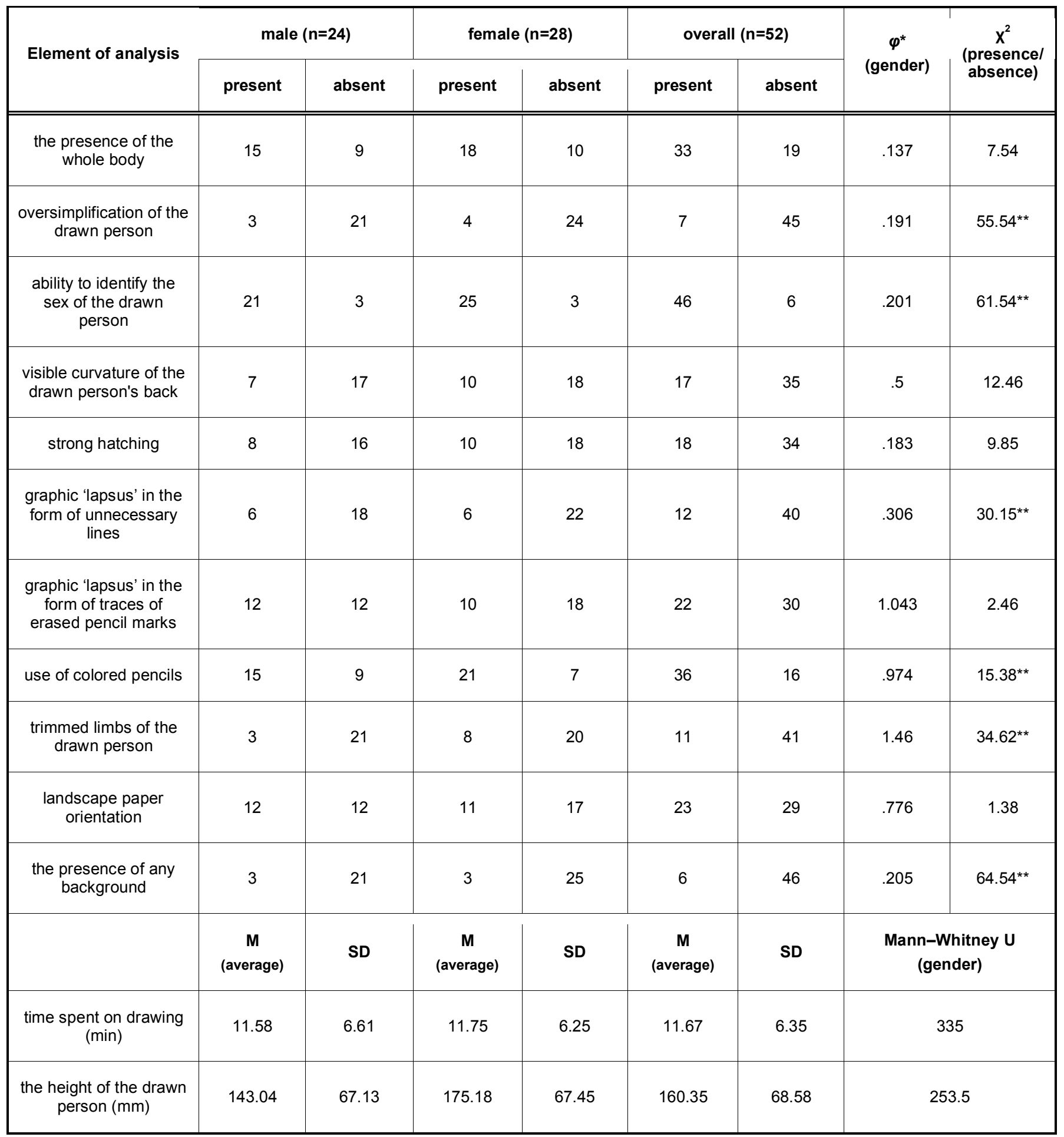

Notes: ${ }^{* *}-p<.01$

\subsection{The Body Image of Adolescents with Scoliosis in Comparison to a Control Group}

Comparing the frequencies of each element from self-portraits of experimental and control groups (Table 3), we have found their similarity by eight scales: the presence of the whole body, oversimplification of the drawn person, ability to identify the sex of the drawn person, strong hatching, graphic 'lapsus' in the form of unnecessary lines or traces of erased pencil marks, limbs of the drawn person are not visible, the presence of any background ( $\varphi^{*}$ between 0 and 1.504, $p>0.05$ ), time spent on drawing $(U=1224, p>0.05)$. 
Table 2: The Body Image (Control Group)

\begin{tabular}{|c|c|c|c|c|c|c|c|c|}
\hline \multirow{2}{*}{ Element of analysis } & \multicolumn{2}{|c|}{ male $(n=24)$} & \multicolumn{2}{|c|}{ female $(n=28)$} & \multicolumn{2}{|c|}{ overall $(n=52)$} & \multirow{2}{*}{$\begin{array}{c}\varphi^{*} \\
\text { (gender) }\end{array}$} & \multirow{2}{*}{$\begin{array}{c}\mathrm{x}^{2} \\
\text { (presence/ } \\
\text { absence) }\end{array}$} \\
\hline & present & absent & present & absent & present & absent & & \\
\hline $\begin{array}{l}\text { the presence of the } \\
\text { whole body }\end{array}$ & 18 & 6 & 22 & 6 & 40 & 12 & .309 & $30.15^{\star \star}$ \\
\hline $\begin{array}{l}\text { oversimplification of the } \\
\text { drawn person }\end{array}$ & 8 & 16 & 2 & 26 & 10 & 42 & $2.484^{* *}$ & $39.38^{\star *}$ \\
\hline $\begin{array}{l}\text { the ability to identify the } \\
\text { sex of the drawn } \\
\text { person }\end{array}$ & 21 & 3 & 27 & 1 & 48 & 4 & 1.226 & $74.46^{\star *}$ \\
\hline $\begin{array}{l}\text { visible curvature of the } \\
\text { drawn person's back }\end{array}$ & 3 & 21 & 5 & 23 & 8 & 44 & .543 & $49.85^{\star \star}$ \\
\hline strong hatching & 4 & 20 & 9 & 19 & 13 & 39 & 1.305 & $26^{* *}$ \\
\hline $\begin{array}{l}\text { graphic 'lapsus' in the } \\
\text { form of unnecessary } \\
\text { lines }\end{array}$ & 6 & 18 & 6 & 22 & 12 & 40 & .306 & $30.15^{\star *}$ \\
\hline $\begin{array}{l}\text { graphic 'lapsus' in the } \\
\text { form of traces of } \\
\text { erased pencil marks }\end{array}$ & 7 & 17 & 11 & 17 & 18 & 34 & .766 & 9.85 \\
\hline use of colored pencils & 3 & 21 & 4 & 24 & 7 & 45 & .157 & $55.54^{\star \star}$ \\
\hline $\begin{array}{l}\text { limbs of the drawn } \\
\text { person are not drawn }\end{array}$ & 2 & 22 & 4 & 24 & 6 & 46 & .69 & $61.54^{\star *}$ \\
\hline $\begin{array}{l}\text { landscape paper } \\
\text { orientation }\end{array}$ & 5 & 19 & 3 & 25 & 8 & 44 & 1.01 & $49.85^{\star \star}$ \\
\hline \multirow[t]{2}{*}{$\begin{array}{l}\text { the presence of any } \\
\text { background }\end{array}$} & 1 & 23 & 7 & 21 & 8 & 44 & $2.279^{*}$ & $49.85^{\star \star}$ \\
\hline & $\begin{array}{c}\text { M } \\
\text { (average) }\end{array}$ & SD & $\begin{array}{c}\text { M } \\
\text { (average) }\end{array}$ & SD & $\begin{array}{c}\text { M } \\
\text { (average) }\end{array}$ & SD & \multicolumn{2}{|c|}{$\begin{array}{l}\text { Mann-Whitney U } \\
\text { (gender) }\end{array}$} \\
\hline $\begin{array}{l}\text { time spent on drawing } \\
(\mathrm{min})\end{array}$ & 6.88 & 6.9 & 13.82 & 6.63 & 10.62 & 7.55 & \multicolumn{2}{|c|}{$159.5^{\star \star}$} \\
\hline $\begin{array}{l}\text { the height of the drawn } \\
\text { person }(\mathrm{mm})\end{array}$ & 109.54 & 64.76 & 129.54 & 52.67 & 120.31 & 58.83 & \multicolumn{2}{|c|}{248} \\
\hline
\end{tabular}

Notes: ${ }^{*} p<.05 ;{ }^{* *} p<.01$.

At the same time, four points were identified as significantly different between the two groups. The most significant difference was the tendency of the adolescents with scoliosis to use colored pencils more frequently $\left(\varphi^{*}=6.185, p<0.01\right)$. On the second place was their landscape orientation of the paper $\left(\varphi^{*}=3.304\right.$, $p<0.01)$. Besides, the experimental group drew a visible curvature of the drawn person's back more often than the control group $\left(\varphi^{*}=2.091, p<0.05\right)$. The absence of difference in the category "presence of the whole body" supports this finding due to the equal number of drawn bodies in both groups. Finally, the size of the drawn body in the experimental group was significantly larger $(U=879.5, p<0.01)$. 
Table 3: The Body Image Differences between the Experimental and Control Groups

\begin{tabular}{|c|c|c|c|c|c|}
\hline \multirow{2}{*}{ Element of analysis } & \multicolumn{2}{|c|}{ experimental group, $(n=52)$} & \multicolumn{2}{|c|}{ control group, $(n=52)$} & \multirow{2}{*}{$\varphi^{*}$} \\
\hline & present & absent & present & absent & \\
\hline presence of the whole body & 33 & 19 & 40 & 12 & 1.504 \\
\hline $\begin{array}{l}\text { oversimplification of the drawn } \\
\text { person }\end{array}$ & 7 & 45 & 10 & 42 & .79 \\
\hline $\begin{array}{l}\text { ability to identify the sex of the } \\
\text { drawn person }\end{array}$ & 46 & 6 & 48 & 4 & .658 \\
\hline $\begin{array}{l}\text { visible curvature of the drawn } \\
\text { person's back }\end{array}$ & 17 & 35 & 8 & 44 & $2.091^{*}$ \\
\hline strong hatching & 18 & 34 & 13 & 39 & 1.076 \\
\hline $\begin{array}{c}\text { graphic 'lapsus' in the form of } \\
\text { unnecessary lines }\end{array}$ & 12 & 40 & 12 & 40 & 0 \\
\hline $\begin{array}{l}\text { graphic 'lapsus' in the form of } \\
\text { traces of erased pencil marks }\end{array}$ & 22 & 30 & 18 & 34 & .806 \\
\hline use of colored pencils & 36 & 16 & 7 & 45 & $6.185^{\star *}$ \\
\hline $\begin{array}{c}\text { limbs of the drawn person are not } \\
\text { visible }\end{array}$ & 11 & 41 & 6 & 46 & 1.351 \\
\hline landscape paper orientation & 23 & 29 & 8 & 44 & $3.304^{* *}$ \\
\hline \multirow[t]{2}{*}{ presence of any background } & 6 & 46 & 8 & 44 & .586 \\
\hline & \multicolumn{2}{|c|}{$\begin{array}{c}\text { M } \\
\text { (average) }\end{array}$} & \multicolumn{2}{|c|}{$\begin{array}{c}\text { M } \\
\text { (average) }\end{array}$} & $\underset{U}{\text { Mann-Whitney }}$ \\
\hline time spent on drawing (min) & \multicolumn{2}{|c|}{11.67} & \multicolumn{2}{|c|}{10.62} & 1224 \\
\hline height of the drawn person $(\mathrm{mm})$ & \multicolumn{2}{|c|}{160.35} & \multicolumn{2}{|c|}{120.31} & $879.5^{\star *}$ \\
\hline
\end{tabular}

Notes: ${ }^{*}-p<.05 ;{ }^{* *}-p<.01$

Considering these results, we noticed some relations between them and the data collected with the Dembo-Rubinstein self-assessment scale. We found a moderate significant direct correlation of the height of the person drawn by the adolescents with scoliosis with their scale "appearance that I can get in future" $(r=0.49$, $\mathrm{p}<0.01)$ and the scale "body that I want to have" $(r=0.359, \quad p<0.01)$; moderate significant direct correlation with the scale "appearance I currently have" $(r=0.313, \quad 0.01<p<0.05)$; weak significant direct correlation with the scale "body I currently have" $(r=0.296,0.01<p<0.05)$.

Comparing the data obtained from both groups from the Dembo-Rubinstein self-assessment scale
(Appendix C), we have found that the adolescents with scoliosis tend to assess the desired level of their health higher than the adolescents from the control group $(\mathrm{U}=$ $1047,0.01<p<0.05)$.

\section{DISCUSSION}

First and foremost, due to the obtained data, we may state that there are certain differences between the adolescents with scoliosis and relevant stigma and the adolescents from the control group in their body image graphic representation. For instance, the research participants from the experimental group drew a visible curvature of the drawn person's back more frequently, though both groups drew their whole bodies 
equally often. This may be understood as a conscious or unconscious graphic manifestation of their scoliosis or being labeled as 'scoliotics' (see examples in Appendix B). This is in line with the other evidence that somatic illnesses (e.g., rheumatoid arthritis, cancer, unilateral cerebral palsy, psoriasis, etc.) tend to predict the specifics of the body image [22, 27, 28, 31]. It may be commented on as both their acceptance or disturbance with their scoliosis, which could be specified only by the interview. This point is especially important due to the fact that these adolescents are involved in everyday struggles with their scoliosis by certain physical training. As if they were identified with 'being a scoliotic' instead of perceiving it as 'almost defeated'. However, only $1 / 3$ of adolescents with scoliosis did, in fact, draw their self-portrait with the curved back, i.e., this point was not common to most experimental group participants.

Another interesting finding was about the reverse correlation of the presence of any background on the self-portraits and the scale "body that I want to have", which was obtained only in the experimental group (i.e., with scoliosis). Therefore, the fact that adolescents with scoliosis tended to draw themselves without any background may prove their high interest in getting an improved body image. However, it was not connected with the image of the body they think they can get in the future. Here we may suppose some gap or conflict between the perceived as realistic and the desired body image. We would hypothesize that in such a situation, they should feel literally alone (i.e., without any background, without any feedback from the others, which means psychological distancing) to keep dreaming of a better body. This point may be associated with being excessively labeled as 'scoliotics', which obstructs their dreams of having a healthy mature body in the future. This is in line with the data of self-assessment of their health. The respondents with scoliosis tended to assess the desired level of health higher than their peers without scoliosis, whilst their hopes to get the assessed health were lower, especially for girls. Thus, the image of the desired healthy body seems overinvested and hard to get.

What was not expected is the fact that the most significant aspects of the drawn body image of the adolescents with scoliosis that differed them from the other peers were as follows:

- $\quad$ they used colored pencils more often;

- they chose landscape orientation of the paper more often;
- $\quad$ they drew a bigger body;

- their drawings had no significant differences related to the respondents' sex.

While boys and girls without scoliosis drew their self-portraits with proven specifics (e.g., boys drew more quickly, and their drawings were oversimplified, while girls paid more attention to the background). Their peers with scoliosis from the specialized sanatorium school did not have any gender difference in any of the studied scales. It is especially interesting because the respondents from both experimental and control groups tended to draw bodies that were clearly attributed to a certain sex. We consider this finding somehow related to the data on usage of colored pencils, landscape orientation, and larger self-portraits.

In summary, considering the findings mentioned above in their combination, we found that adolescents from the experimental group tended to use colored pencils and landscape paper orientation more frequently as well as to draw larger bodies in their selfportraits. These findings can be interpreted in terms of the common features of children's drawing: the older he or she gets, the more important the form becomes in perception and reflection instead of colors [68, 69]. In other words, the drawings made by adolescents with scoliosis look more childish than the drawings of their peers from the control group. This idea may be illustrated by one more finding in our previous research [70]; there was a moderate reverse correlation between the use of colored pencils while drawing by the experimental group and the scale "anticipation" ( $r=-$ $0.345,0.01<p<0.05)$. The lack of anticipation, common for mid-adolescents [71, 72], may also prove some infantile processes in experiencing the bodies of adolescents with scoliosis. This faces us with $\mathrm{S}$. Lesourd's idea that adolescence is not the chronological age but logical [4]; therefore, most studied respondents from the experimental group may function more like children than adolescents. For instance, lack of gender difference in drawings with, however, identified ('the known') sex of the people in the portraits may mark here some dynamics from the latent psychosexual phase with its repressed sexuality [3].

As for the tendency to draw themselves taller adolescents with scoliosis, the standard interpretation would state they have higher levels of self-esteem and a sense of safety while drawing themselves [66, 67]. However, we have found several specific correlations with this category that seem to have different 
meanings. In particular, we found interesting the fact that the mentioned height is in reverse correlation with the drawing of the whole body. This means that the height is rather a characteristic of the drawn part of the body (mostly, the head with shoulders), which is the body part where scoliosis does not exist or is nearly invisible. It raises a lot of questions. For instance, do some adolescents with scoliosis deny ('delete in conscious perception') their scoliosis for better selfesteem? This is in line with the other data obtained in the study, e.g., that the height of the portrayed self is more about the desired image of their bodies and its appearance than about the current situation.

Besides, we can connect these considerations with the choice of landscape orientation of the drawing. This single observation could be interpreted as a feeling of freedom in choosing different drawing tools [68, 69]. Nevertheless, along with the fact of drawing a taller person, it looks like the existence of something like a "low ceiling". In a room with a low ceiling, you have to bend your back. Such drawings look as if there is someone big, i.e., older, placed in the conditions for smaller ones. Besides, drawing on a piece of paper flipped horizontally, withdrawing of a big and colored body, is again associated with a child's work.

As for the adolescents from the control group, it was important to find that their graphic 'lapsus' was evidence of dissatisfaction with their currently experienced health. This may strengthen the validity of projective methods of diagnostics in the topic of some 'graphic mistakes'.

\section{LIMITATIONS}

The study has several limitations, which we associate with the sample size, sample specifics, and the research design. First of all, the number of research participants with scoliosis was limited to the available pupils of one certain specialized (and stigmatized) educational institution. The second is that the control group was equal in size and, thus, small as well. What is even more important is that the control group included only adolescents without scoliosis, and we, however, suppose that one more control group with adolescents with scoliosis who go to ordinary secondary schools would help to separate the findings which describe the influence of scoliosis from the findings on the influence of labeling an adolescent as 'a scoliotic'. One more limitation is associated with the research design, which was built on non-standardized methods and involved only one researcher for raw data collection.

\section{CONCLUSIONS}

The body image is to be reconsidered and reconstructed during adolescence, which is proven to be more difficult in case of somatic or psychic illness and social stigma. The adolescents with scoliosis and labeled as 'scoliotics' due to their special educational institution face additional obstructions in their psychic body development. For instance, they tend to overinvest in the desired image of a healthy body and do not feel able to get it one day. In our study, we found the graphic markers of four different ways to cope with the situation by the studied adolescents with scoliosis: (a) identification of self as 'a scoliotic' instead of hope to be cured soon; (b) psychological distancing from the others to preserve the desire of a more attractive body image; (c) repression or denial of the body parts that could be related to scoliosis; (d) infantilization aimed to slow down the discovery of their own maturing corporeality. Consequently, adolescents with scoliosis affected by stigma experience the gap or conflict between their current, desired and perceived as realistic body image.

\section{FUNDING}

This research did not receive any specific grant from funding agencies in the public, commercial, or notfor-profit sectors.

\section{APPENDICES}

\section{Appendix A}

Table A1:

\begin{tabular}{|c|c|c|c|}
\hline № & $\begin{array}{c}\text { Element of a } \\
\text { drawing }\end{array}$ & Description & Example \\
\hline \hline
\end{tabular}




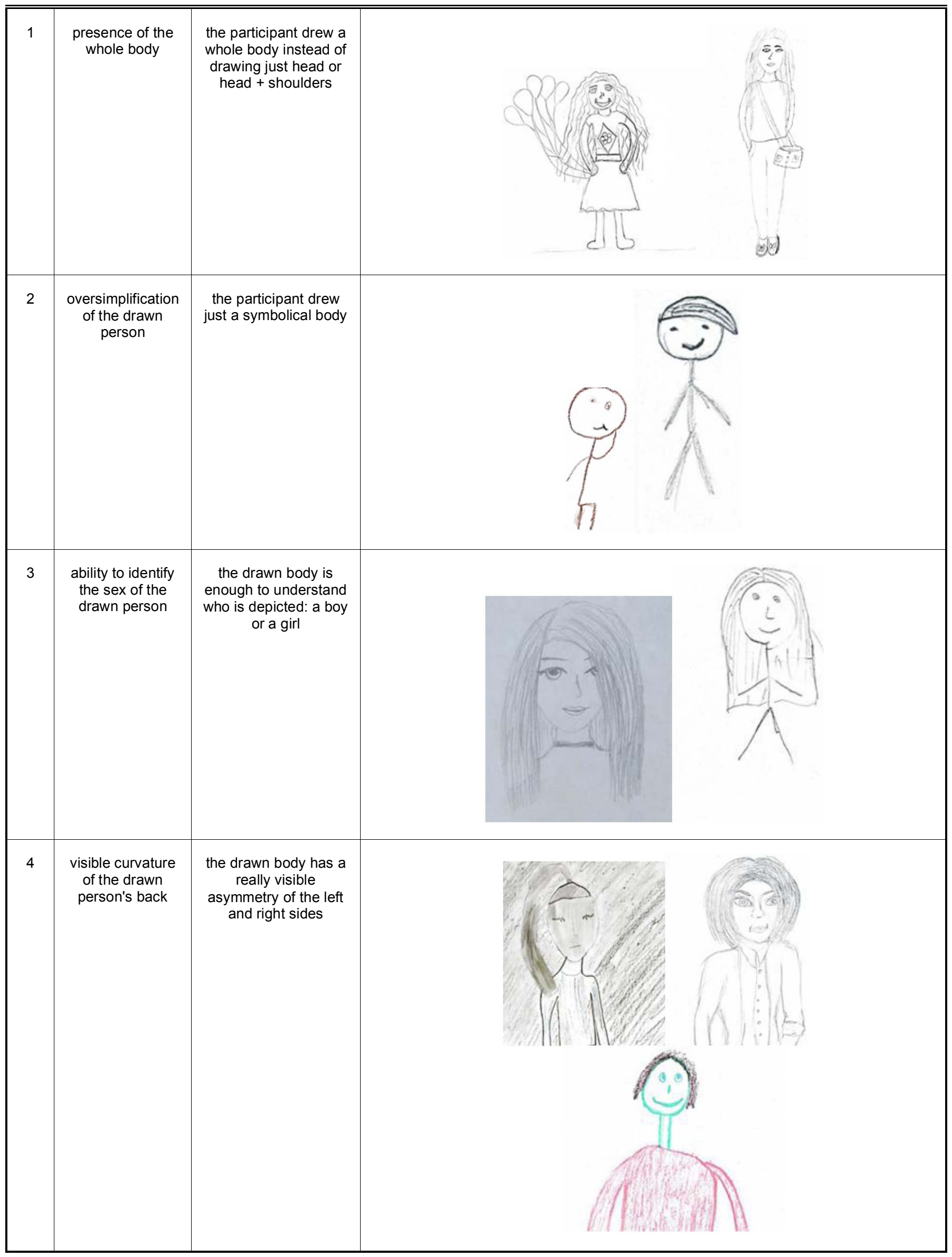




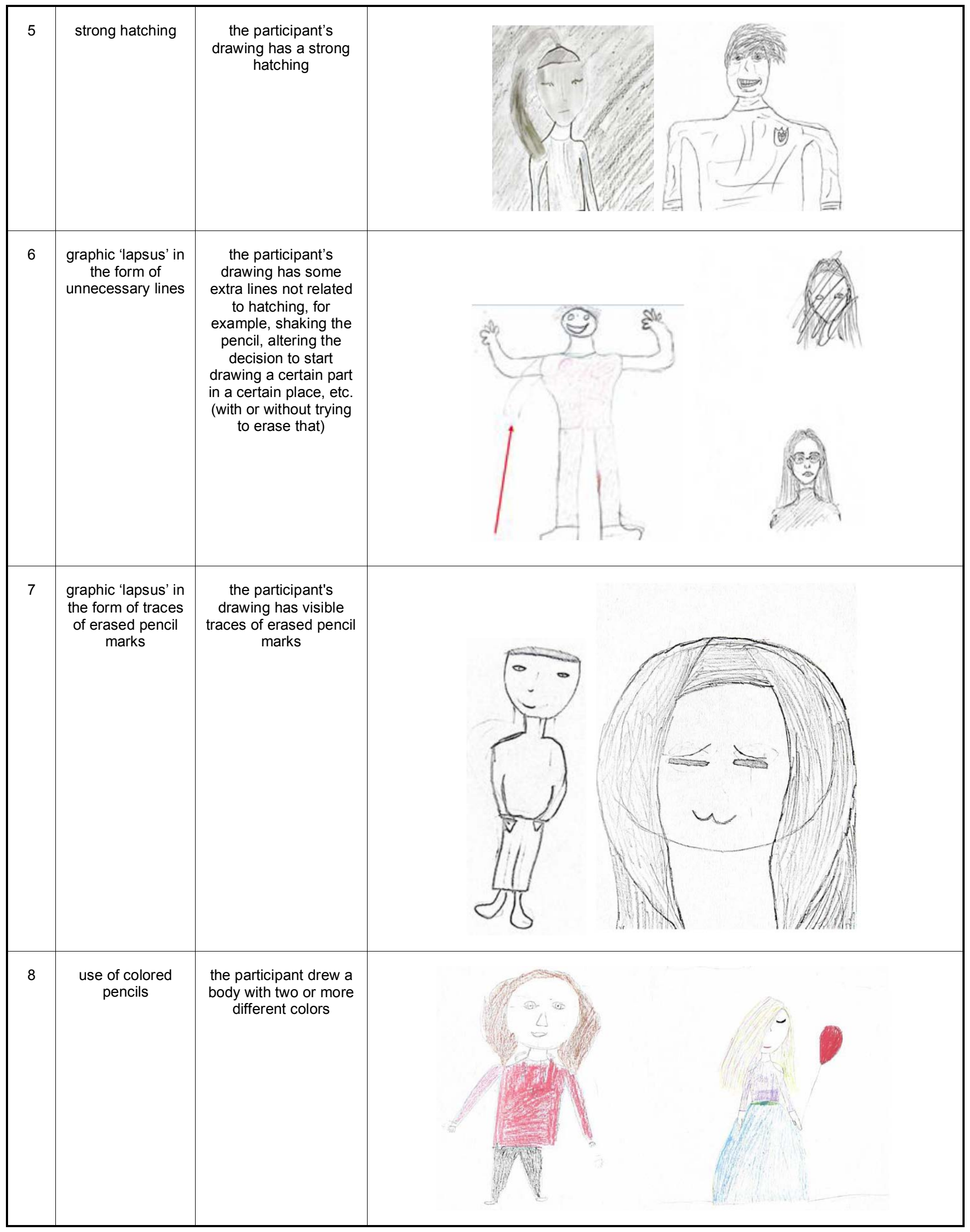




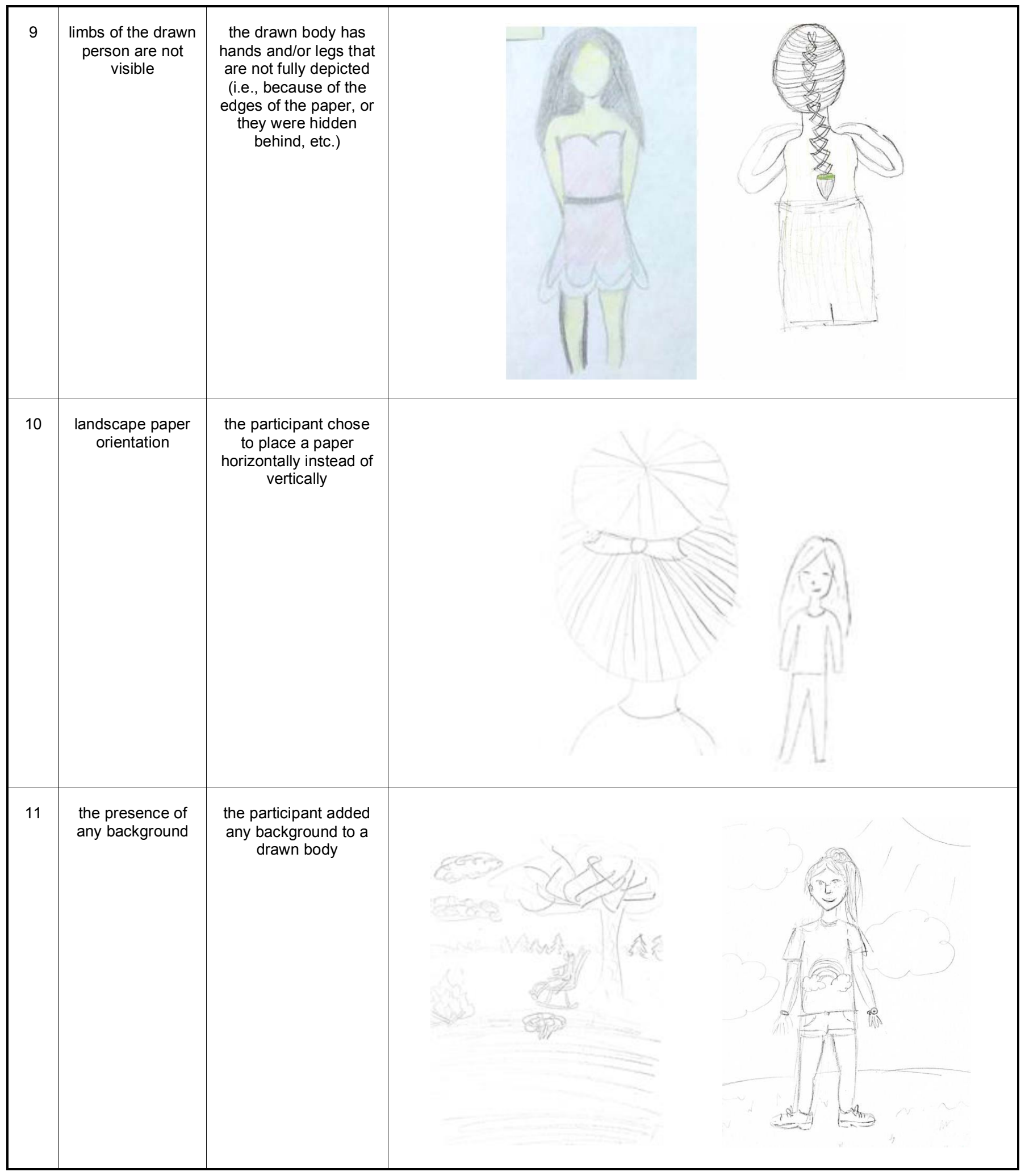




\section{Appendix B}

\section{Instructions}

Let's imagine that at the top of the first line there is the healthiest human in the world, while at the bottom there is the sickest human in the world, and between them, there is all the humanity including you, me, and every person you know. Answer the questions by putting the appropriate mark:

(1) where are you now between them? (-); (2) where do you want to be? (o); where can you get in the future? (V). On the other lines, answer the same questions, paying attention to the line category indicated below them.
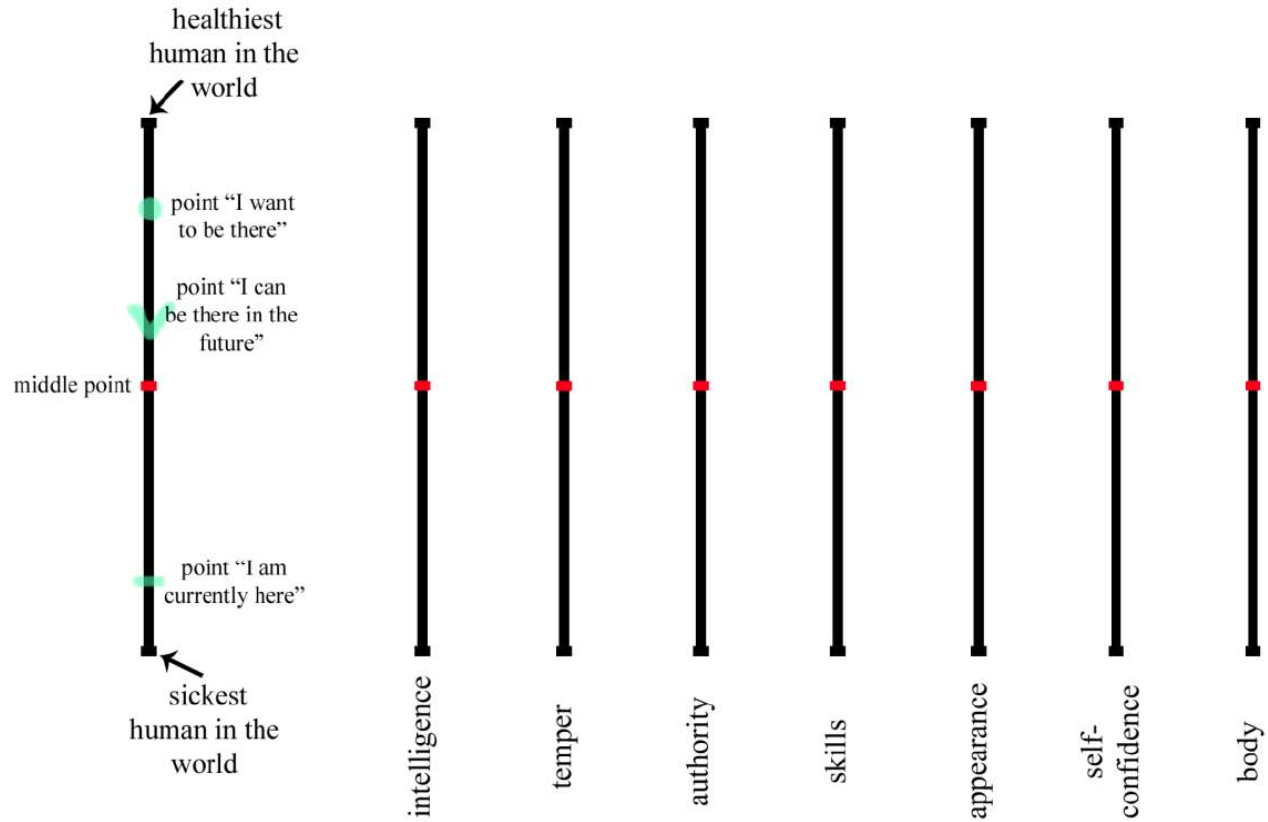

Figure B1: Dembo-Rubinstein self-assessment scale's blank.

\section{Appendix C}

Table C1:

\begin{tabular}{|c|c|c|c|c|c|c|c|c|c|}
\hline \multirow{2}{*}{ Scale } & \multicolumn{4}{|c|}{ Experimental group } & \multicolumn{4}{|c|}{ Control group } & \multirow{2}{*}{$\begin{array}{c}\text { Mann- } \\
\text { Whitney U } \\
\text { (groups) }\end{array}$} \\
\hline & $\begin{array}{c}\text { M } \\
\text { (average) }\end{array}$ & $\begin{array}{c}\text { male } \\
(n=24)\end{array}$ & $\begin{array}{l}\text { female } \\
(n=28)\end{array}$ & $\begin{array}{c}\text { Mann- } \\
\text { Whitney U } \\
\text { (gender) }\end{array}$ & $\begin{array}{c}\text { M } \\
\text { (average) }\end{array}$ & $\begin{array}{c}\text { male } \\
(n=24)\end{array}$ & $\begin{array}{l}\text { female } \\
(n=28)\end{array}$ & $\begin{array}{c}\text { Mann- } \\
\text { Whitney U } \\
\text { (gender) }\end{array}$ & \\
\hline $\begin{array}{c}\text { "health I want to } \\
\text { have" }\end{array}$ & 92.29 & 93.13 & 91.57 & 330 & 87.15 & 85.79 & 88.32 & 289 & $1047^{*}$ \\
\hline $\begin{array}{l}\text { "health I can get } \\
\text { in future" }\end{array}$ & 78.27 & 83.58 & 73.71 & $206^{* *}$ & 74.87 & 77.17 & 72.89 & 310 & 1247 \\
\hline
\end{tabular}




\begin{tabular}{|c|c|c|c|c|c|c|c|c|c|}
\hline $\begin{array}{c}\text { "body I want to } \\
\text { have" }\end{array}$ & 86.38 & 84.63 & 87.89 & 323.5 & 80.92 & 78.04 & 83.39 & 279 & 1105.5 \\
\hline $\begin{array}{l}\text { "body I can get } \\
\text { in the future" }\end{array}$ & 73.87 & 75.79 & 72.21 & 290 & 70.21 & 70.83 & 69.68 & 327.5 & 1299 \\
\hline $\begin{array}{l}\text { "appearance I } \\
\text { currently have" }\end{array}$ & 52.17 & 53.33 & 51.18 & 312 & 57.92 & 60.38 & 55.82 & 326 & 1192 \\
\hline $\begin{array}{l}\text { "appearance I } \\
\text { want to have" }\end{array}$ & 78.54 & 72.08 & 84.07 & 252.5 & 81.85 & 78.46 & 84.75 & $234^{*}$ & 1233.5 \\
\hline $\begin{array}{c}\text { "appearance I } \\
\text { can get in the } \\
\text { future" }\end{array}$ & 71.42 & 71.83 & 71.07 & 310 & 71.35 & 69.58 & 72.86 & 277 & 1299 \\
\hline
\end{tabular}

Notes: ${ }^{*}-p<0.05 ;{ }^{* *}-p<0.01$.

\section{REFERENCES}

[1] Dolto F. La Cause des adolescents. Paris: Robert Laffont; 1988.

[2] Lesourd S. Adolescences Rencontre du féminin. Ramonville Saint-Ange: Érès; 2002.

[3] Freud S. Three essays on the theory of sexuality. In: Freud S, Ed. Inhibitions, symptoms, and anxiety. 1905; pp. 125243.

[4] Lesourd S. La construction adolescente. Ramonville SaintAnge: Érès; 2013

[5] Velykodna M. Le corps comme garantie pour l'Autre. Childobject, child-subject: XIX seminar of Freud's field in Ukraine (April 20-21, 2013, Simferopol, Crimea) 2013: 87-94.

[6] Gleeson K, Frith H. (De) constructing body image. J Health Psychol 2006; 11: 79-90. https://doi.org/10.1177/1359105306058851

[7] Carlson Jones D. Body image among adolescent girls and boys: a longitudinal study. Developmental Psychology 2004; 40: 823.

https://doi.org/10.1037/0012-1649.40.5.823

[8] Çok F. Body image satisfaction in Turkish adolescents. Adolescence 1990; 98: 409.

[9] Croll J. Body image and adolescents. Chest 2005; 40: 50.

[10] Davison TE, McCabe MP. Adolescent body image and psychosocial functioning. J Soc Psychol 2006; 146: 15-30. https://doi.org/10.3200/SOCP.146.1.15-30

[11] McCabe MP, Ricciardelli LA. Sociocultural influences on body image and body changes among adolescent boys and girls. J Soc Psychol 2003; 143: 5-26. https://doi.org/10.1080/00224540309598428

[12] Marengo D, Longobardi C, Fabris MA, Settanni M. Highlyvisual social media and internalizing symptoms in adolescence: The mediating role of body image concerns. Comput Human Behav 2018; 82: 63-9. https://doi.org/10.1016/j.chb.2018.01.003

[13] Markey CN. Invited commentary: Why body image is important to adolescent development. J Youth Adolescence 2010; 39: 1387-91 https://doi.org/10.1007/s10964-010-9510-0

[14] Morrison TG, Kalin R, Morrison MA. Body-image evaluation and body-image among adolescents: a test of sociocultural and social comparison theories. Adolescence 2004; 39: 57192.

[15] Ramos P, Moreno-Maldonado C, Moreno C, Rivera F. The role of body image in internalizing mental health problems in Spanish adolescents: an analysis according to sex, age, and socioeconomic status. Front Psychol 2019; 10: 1952. https://doi.org/10.3389/fpsyg.2019.01952
[16] Ricciardelli LA. Body image development - adolescent boys. In: Cash TF, Ed. Encyclopedia of body image and human appearance. Elsevier Academic Press 2012; p. 180-6.

[17] Rodgers RF, Donovan E, Cousineau T, et al. BodiMojo: Efficacy of a mobile-based intervention in improving body image and self-compassion among adolescents. J Youth Adolesc 2018; 47: 1363-72. https://doi.org/10.1007/s10964-017-0804-3

[18] Senín-Calderón C, Rodríguez-Testal JF, Perona-Garcelán S Perpiñá C. Body image and adolescence: A behavioral impairment model. Psychiatry Res 2017; 248: 121-6. https://doi.org/10.1016/j.psychres.2016.12.003

[19] Wertheim EH, Paxton SJ. Body image development in adolescent girls. In: Cash TF, Smolak L, Eds. Body image: A handbook of science, practice, and prevention. New York: The Guilford Press 2011; pp. 76-84.

[20] Badoud D, Tsakiris M. From the body's viscera to the body's image: Is there a link between interoception and body image concerns? Neurosci Biobehav Rev 2017; 77: 237-46. https://doi.org/10.1016/j.neubiorev.2017.03.017

[21] Vignemont F. Body schema and body image - pros and cons. Neuropsychologia 2010; 48: 669-80. https://doi.org/10.1016/j.neuropsychologia.2009.09.022

[22] Nuara A, Papangelo P, Avanzini P, Fabbri-Destro M. Body representation in children with unilateral cerebral palsy. Front Psychol 2019; 10: 354.

https://doi.org/10.3389/fpsyg.2019.00354

[23] Gallagher S. How the body shapes the mind? Oxford: Oxford University Press; 2005. https://doi.org/10.1093/0199271941.001.0001

[24] Slade PD. What is body image? Behav Res Ther 1994; 32 497-502. https://doi.org/10.1016/0005-7967(94)90136-8

[25] Tylka TL. Positive psychology perspectives on body image. In: Cash TF, Smolak L, Eds. Body image: A handbook of science, practice, and prevention. New York: The Guilford Press 2011; pp. 56-64

[26] Tylka TL. Overview of the field of positive body image. In: Daniels EA, Gillen M, Markey $\mathrm{CH}$, Eds. Body positive: Understanding and improving body image in science and practice. Cambridge University Press 2018; p. 6-33. https://doi.org/10.1017/9781108297653.002

[27] Hopwood P, Fletcher I, Lee A, Al Ghazal S. A body image scale for use with cancer patients. Eur J Cancer 2001; 37: 189-97. https://doi.org/10.1016/S0959-8049(00)00353-1

[28] Rzeszutek M, Pięta M, Huzar M. Profiles of resources and body image in health and illness: A comparative study 
among females with rheumatoid arthritis, females with breast cancer, and healthy controls. Brain Behav 2020; 10: e01488. https://doi.org/10.1002/brb3.1488

[29] McCarthy A. Summer camp for children and adolescents with chronic conditions. Pediatr Nurs 2015; 41: 245

[30] Taleporos G, McCabe MP. Body image and physical disability - personal perspectives. Soc Sci Med 2002; 54: 971-80. https://doi.org/10.1016/S0277-9536(01)00069-7

[31] Nazik H, Nazik S, Gul FC. Body image, self-esteem, and quality of life in patients with psoriasis. Indian Dermatol Online J 2017; 8: 343. https://doi.org/10.4103/idoj.IDOJ_503_15

[32] Velykodna M, Edelieva K. The issue of adolescence in psychoanalysis: theory, techniques, and ethics of practical work. Habitus 2020; 12: 11-7. https://doi.org/10.32843/2663-5208.2020.12-2.1

[33] Stanghellini G, Ballerini M, Blasi $\mathrm{S}$, et al. The bodily self: $\mathrm{A}$ qualitative study of abnormal bodily phenomena in persons with schizophrenia. Compr Psychiatry 2014; 55: 1703-11. https://doi.org/10.1016/j.comppsych.2014.06.013

[34] Derenne JL, Beresin EV. Body image, media, and eating disorders. Acad Psychiatry 2006; 30: 257-61. https://doi.org/10.1176/appi.ap.30.3.257

[35] Fogelkvist M, Gustafsson SA, Kjellin L, Parling T Acceptance and commitment therapy to reduce eating disorder symptoms and body image problems in patients with residual eating disorder symptoms: A randomized controlled trial. Body Image 2020; 32: 155-66. https://doi.org/10.1016/j.bodyim.2020.01.002

[36] McLean SA, Paxton SJ. Body image in the context of eating disorders. Psychiatr Clin North Am 2019; 42: 145-56. https://doi.org/10.1016/j.psc.2018.10.006

[37] Smolak L, Levine MP. Body image in children. In: Thompson JK, Smolak L, Eds. Body image, eating disorders, and obesity in youth: Assessment, prevention, and treatment. American Psychological Association 2001; pp. 41-66. https://doi.org/10.1037/10404-002

[38] Walker DC., White EK, Srinivasan VJ. A meta-analysis of the relationships between body checking, body image avoidance, body image dissatisfaction, mood, and disordered eating. Int J Eat Disord 2018; 51: 745-70. https://doi.org/10.1002/eat.22867

[39] Noles SW, Cash TF, Winstead BA. Body image, physical attractiveness, and depression. J Consult Clin Psychol 1985; 53: 88-94.

https://doi.org/10.1037/0022-006X.53.1.88

[40] Altabe M. Ethnicity and body image: Quantitative and qualitative analysis. Int J Eat Disord 1998; 23: 153-9. https://doi.org/10.1002/(SICl)1098108X(199803)23:2<153::AID-EAT5>3.0.CO;2-J

[41] Cafri G, Yamamiya Y, Brannick M, Thompson JK. The influence of sociocultural factors on body image: A meta-analysis. Clin Psychol 2005; 12: 421-33. https://doi.org/10.1093/clipsy.bpi053

[42] Fallon A. Culture in the mirror: sociocultural determinants of body image. In: Cash TF, Pruzinsky T, Eds. Body images: Development, deviance, and change. New York: Guilford Press 1990; pp. 80-109.

[43] Grogan S. Body Image and Health: Contemporary Perspectives. J Health Psychol 2006; 11: 523-30. https://doi.org/10.1177/1359105306065013

[44] Levine MP, Chapman K. Media influences on body image. In: Cash TF, Smolak L, Eds. Body image: A handbook of science, practice, and prevention. New York: The Guilford Press 2011; pp. 101-9.

[45] Myers PN, Biocca FA. The elastic body image: The effect of television advertising and programming on body image distortions in young women. J Commun 1992; 42: 108-33. https://doi.org/10.1111/j.1460-2466.1992.tb00802.x
[46] Paquette MC, Raine K. Sociocultural context of women's body image. Soc Sci Med 2004; 59: 1047-58.

https://doi.org/10.1016/j.socscimed.2003.12.016

[47] Smolak L. Body Image. In: Worell J, Goodheart CD, Eds Oxford series in clinical psychology. Handbook of girls' and women's psychological health: Gender and well-being across the lifespan. Oxford University Press 2006; pp. 69-76.

[48] Stojcic I, Dong X, Ren X. Body image and sociocultural predictors of body image dissatisfaction in Croatian and Chinese women. Front Psychol 2020; 11: 731. https://doi.org/10.3389/fpsyg.2020.00731

[49] Tiggemann M. Sociocultural perspectives on body image. In: Cash TF, Ed. Encyclopedia of body image and human appearance. Elsevier Academic Press 2012; pp. 758-65.

[50] Tiggemann M, Slater A. NetGirls: The Internet, Facebook, and body image concern in adolescent girls. Int $\mathrm{J}$ Eat Disord 2013; 46: 630-3.

https://doi.org/10.1002/eat.22141

[51] Thompson JK, Heinberg LJ, Altabe M, Tantleff-Dunn S Exacting beauty: Theory, assessment, and treatment of body image disturbance. American Psychological Association; 1999.

https://doi.org/10.1037/10312-000

[52] Askevold F. Measuring body image. Psychother Psychosom 1975; 26: 71-7. https://doi.org/10.1159/000286913

[53] Banfield SS, McCabe M. An evaluation of the construct of body image. Adolescence 2002; 37: 373-93.

[54] Cafri G, Thompson JK. Measuring male body image: A review of the current methodology. Psychol Men Masc 2004; 5: 18. https://doi.org/10.1037/1524-9220.5.1.18

[55] Cash TF. Body-image attitudes: Evaluation, investment, and affect. Percept Mot Skills 1994; 78(3 suppl): 1168-70. https://doi.org/10.2466/pms.1994.78.3c.1168

[56] Cash TF. Crucial considerations in the assessment of body image. In: Cash TF, Smolak L, Eds. Body image: A handbook of science, practice, and prevention. New York: The Guilford Press 2011; pp. 129-37.

[57] Cash TF, Fleming EC, Alindogan J, Steadman L, Whitehead A. Beyond body image as a trait: The development and validation of the Body Image States Scale. Eat Disord 2002; 10: 103-13. https://doi.org/10.1080/10640260290081678

[58] Cash TF, Fleming EC. The impact of body image experiences: Development of the body image quality of life inventory. Int J Eat Disord 2002; 31: 455-60.

https://doi.org/10.1002/eat.10033

[59] Lindgren TW, Pauly IB. A body image scale for evaluating transsexuals. Arch Sex Behav 1975; 4: 639-56.

https://doi.org/10.1007/BF01544272

[60] Littleton HL, Axsom D, Pury CL. Development of the body image concern inventory. Behav Res Ther 2005; 43: 229-41. https://doi.org/10.1016/j.brat.2003.12.006

[61] Rosen JC, Srebnik D, Saltzberg E, Wendt S. Development of a body image avoidance questionnaire. Psychological Assessment: J Consult Clin Psychol 1991; 3: 32. https://doi.org/10.1037/1040-3590.3.1.32

[62] Sandoz EK, Wilson KG, Merwin RM, Kellum KK. Assessment of body image flexibility: The body image-acceptance and action questionnaire. J Contextual Behav Sci 2013; 2: 39-48. https://doi.org/10.1016/j.jcbs.2013.03.002

[63] Thompson JK. Body image disturbance: Assessment and treatment. Oxford: Pergamon Press 1990.

[64] Goodenough FL. Measurement of Intelligence by Drawings. New York: Arno Press 1975.

[65] Prikhozhan AM. Application of direct assessment methods in the work of a school psychologist [In Russian]. Scientific and 
methodological foundations for the use of specific psychological techniques in the 74 schools psychological service 1988; 1: 110-118

[66] Burns RC, Kaufman SH. Actions, styles, and symbols in kinetic family drawings: An interpretative manual. New York: Brunner/Mazel; 1972.

[67] Romanova ES, Potemkina OF. Graphic methods in psychological diagnostics [In Russian]. Moscow: Didakt 1992.

[68] Ignatiev SE. Regularities of children's imaging activities [In Russian]. Moscow: Academic Project; 2007.

[69] Lykova ES. Analysis of age characteristics of children's drawings [In Russian]. Bulletin of the Siberian institute of business and information technologies 2016; 3: 134-9.
[70] Deputatov VO. Mechanisms of psychological defense and coping strategies of adolescents with scoliosis: empirical research. Habitus 2020; 12: 110-5.

https://doi.org/10.32843/2663-5208.2020.12-2.18

[71] Hoogendam JM, Kahn RS, Hillegers MH, van Buuren M, Vink M. Different developmental trajectories for anticipation and receipt of reward during adolescence. Dev Cogn Neurosci 2013; 6: 113-24.

https://doi.org/10.1016/j.dcn.2013.08.004

[72] Lamm C, Benson BE, Guyer AE, et al. Longitudinal study of striatal activation to reward and loss anticipation from midadolescence into late adolescence / early adulthood. Brain Cogn 2014; 89: 51-60

https://doi.org/10.1016/j.bandc.2013.12.003

Received on 25-03-2021

Accepted on 20-05-2021

Published on 27-05-2021

https://doi.org/10.6000/1929-4247.2021.10.02.3

(c) 2021 Deputatov and Velykodna; Licensee Lifescience Global.

This is an open access article licensed under the terms of the Creative Commons Attribution Non-Commercial License (http://creativecommons.org/licenses/by-nc/3.0/) which permits unrestricted, non-commercial use, distribution and reproduction in any medium, provided the work is properly cited. 